\title{
GAMBARAN PERILAKU SEKSUAL PRANIKAH PADA REMAJA DI SMK X KABUPATEN BOGOR TAHUN 2019
}

\author{
Muhammad Darusman ${ }^{1)}$, Andreanda Nasution ${ }^{2)}$, Supriyanto $^{3)}$
}

\author{
${ }^{1)}$ Konsentrasi Promosi Kesehatan, Program Studi Kesehatan Masyarakat, Fakultas Ilmu Kesehatan, Universitas Ibn \\ Khaldun Bogor. \\ Email: darusmanmhamad11@gmail.com \\ ${ }^{2)}$ Konsentrasi Promosi Kesehatan, Program Studi Kesehatan Masyarakat, Fakultas Ilmu Kesehatan, Universitas Ibn \\ Khaldun Bogor. \\ Email: andre.anda8861@gmail.com \\ ${ }^{3)}$ Konsentrasi Promosi Kesehatan, Program Studi Kesehatan Masyarakat, Fakultas Ilmu Kesehatan, Universitas Ibn \\ Khaldun Bogor. \\ Email: Supriyanto1953_@yahoo.com
}

\begin{abstract}
Abstrak
Isu seksualitas dan kesehatan reproduksi yang tabu untuk di bicarakan menjadikan remaja cenderung ingin mencoba-coba sehingga remaja menjadi berisiko pada perilaku seks yang berdampak pada kehamilan yang tidak di inginkan dan masih banyak lagi. Penelitian ini dilakukan untuk mengetahui Gambaran perilaku seksual pranikah pada remaja di SMK X Kabupaten Bogor Tahun 2019. Penelitian ini merupakan penelitian kualitatif yang di lakukan dengan metode wawancara mendalam dan menggunakan pedoman wawancara, informan dalam penelitian ini berjumlah 15 orang dan proses pengambilan data dilakukan pada bulan maret 2019. Dari hasil penelitian didapatkan pengetahuan informan dalam hal ini cukup baik, hanya saja informan menjelaskan perilaku seksual secara umum yang sering di lihat atau di ceritakan tidak secara medalam, dalam peran orangtua sebenarnya sudah baik, tetapi masih banyak dari orangtua dan informan yang di teliti masih tabu untuk di bicarakan, dalam ketaatan agama di dapatkan bahwa banyak yang hanya mengikuti agenda kegamaan di sekolah dan di lingkungan masyarakat tidak ada kegiatan keagamaan lainya.
\end{abstract}

Kata Kunci : seksual, remaja, pengetahuan

\section{Pendahuluan}

Berdasarkan data World Health Organization (WHO) tahun 2013, tercatat perilaku seksual di Afrika, Bangladesh, India, Nepal, Yaman, Amerika Latin dan Karibia, sebanyak $40 \%$ - $80 \%$ perempuan telah aktif dalam seksualitas pada usia 18 tahun, begitu juga di Uganda, sebanyak 4\% laki-laki berusia 10 tahun mengatakan mereka sudah pernah melakukan hubungan seksual, 10\% pada usia 12 tahun, 22\% pada usia 14 tahun, dan 64\% pada usia 18 tahun.

Survey Demografi Kesehatan Indonesia (2012) remaja usia 15-19 tahun telah melakukan hubungan seksual ketika berpacaran hal ini dapat dilihat remaja melakukan aktifitas berciuman bibir pada wanita 23,6\% dan laki-laki 37,3\%, meraba/merangsang pada wanita $4,3 \%$ dan laki-laki $21,6 \%$, sedangkan hubungan intim 
pranikah pada wanita $0,7 \%$ dan laki-laki $4,5 \%$. Beberapa perilaku tersebut bisa mengantar pada resiko kehamilan yang tidak diinginkan atau kehamilan diluar nikah, diindonesia remaja wanita sebanyak 28,3\% telah mengalami hamil diluar nikah.

Fenomena yang terjadi di masyarakat saat ini menunjukkan bahwa perilaku seksual remaja dan seks pra nikah pada remaja terus meningkat dari tahun ke tahun. Data dan survei yang dilakukan oleh BKKBN tahun 2010 sebanyak 51\% remaja di Jakarta,Bogor, Depok, Tangerang dan Bekasi (Jabodetabek), pernah berhubungan seks.Surabaya tercatat $54 \%$, di Bandung 47\%, dan 53\% di Medan. Angka tersebut naik di bandingkan dengan tahun- tahun sebelumnya. Fenomena ini menunjukkan bahwa perilaku seksual remaja di berbagai kota di Indonesia hampir sama.

Data mengejutkan baru baru ini dirilis oleh Dinas Kesehatan Kota Bogor dalam jangka waktu satu tahun sedikitnya terdapat

\section{Metode}

Metode yang di gunakan pada penelitian ini adalah metode kualitatif dengan jenis penelitian Fenomenologi dan peneliti menggunakan teknik wawancara mendalam. Populasi dalam penelitian ini adalah seluruh remaja SMK X di Kabupaten Bogor yang berjumlah 83 siswa, sedangkan jumlah sampel yang digunakan yaitu meliputi 10
32 kasus kehamilan yang tidak diinginkan dari 148 kasus hubungan seks pranikah. (Dinkes Kota Bogor, 2014) Artinya terdapat dari 148 kasus hubungan seksual di luar nikah, terdapat 32 kasus aborsi selama setahun ini di daerah Bogor kota. Entah berapa banyak lagi kasus yang tidak terdata.

Dalam penelitian yang dilakukan oleh Anggraeni (2012) dari FKM UI dengan judul hubungan antara pengetahuan seks pranikah terhadap sikap seks pranikah remaja SMKN 1 Bogor. Penelitian tersebut melibatkan 330 responden dan memperoleh hasil bahwa ada hubungan antara pengetahuan seks pranikah terhadap seks pranikah responden, hal ini menunjukan korelasi yang positif dengan kekuatan atau keeratan hubungan yang rendah $(\mathrm{R}=0.189)$. artinya semakin tinggi pengetahuan seks pranikah maka semakin tinggi sikap seks pranikahnya. Hubungan ini bermakna secara statistik dengan $p$ value 0,001 .

informan inti dan 5 informan kunci. Data primer dikumpulkan dengan cara wawancara mendalam dan data sekunder di dapatkan dari SMK X Kabupaten Bogor yang meliputi jumlah siswa dan jabatan guru. penelitian ini dilakukan selama 4 bulan dari januari - april 2019, sedangkan untuk pengambilan data dilakukan selama 2 minggu.

\section{Hasil Penelitian}

\section{Karakteristik Informan}

Tabel 1 Karakteristik Informan Inti yang sedang Berpacaran

\begin{tabular}{|c|c|c|c|c|}
\hline Kode & Kelas & Usia & Jenis Kelamin & Keterangan \\
\hline Informan (A1) & 11 & 16 Tahun & Perempuan & Sedang pacaran \\
\hline Informan (A2) & 11 & 16 Tahun & Perempuan & Sedang pacaran \\
\hline Informan (A3) & 11 & 16 Tahun & Perempuan & Sedang pacaran \\
\hline Informan (A4) & 12 & 17 Tahun & Perempuan & Sedang pacaran \\
\hline Informan (A5) & 12 & 17 Tahun & Perempuan & Sedang pacaran \\
\hline
\end{tabular}


Tabel 2 Karakteristik Informan Inti yang pernah Berpacaran

\begin{tabular}{|c|c|c|c|c|}
\hline Kode & Kelas & Usia & Jenis Kelamin & Keterangan \\
\hline Informan (B1) & XI & 16 Tahun & Perempuan & Pernah pacaran \\
\hline Informan (B2) & XII & 17 Tahun & Perempuan & Pernah pacaran \\
\hline Informan (B3) & XII & 17 Tahun & Perempuan & Pernah Pacaran \\
\hline Informan (B4) & XII & 17 Tahun & Laki-laki & Pernah pacaran \\
\hline Informan (B5) & XII & 17 Tahun & Perempuan & Pernah Pacaran \\
\hline
\end{tabular}

Tabel 3 Karakteristik Informan Kunci

\begin{tabular}{|c|c|c|c|c|}
\hline No & Informan Kunci & Jumlah & Usia & Pendidikan \\
\hline 1. & $\begin{array}{c}\text { Guru BP/BK SMK X Kabupaten Bogor } \\
\text { (Informan Kunci I ) }\end{array}$ & 1 & 35 Tahun & Pascasarjana \\
\hline 2. & $\begin{array}{c}\text { Guru Kesiswaan SMK X Kabupaten Bogor } \\
\text { (Informan Kunci II ) }\end{array}$ & 1 & 49 Tahun & Sarjana \\
\hline 3. & $\begin{array}{c}\text { Wali Kelas SMK X Kabupaten Bogor } \\
\text { (Informan Kunci III ) }\end{array}$ & 2 & 24 Tahun & Sarjana \\
\hline 4. & $\begin{array}{c}\text { Kepala Sekolah SMK X Kabuipaten Bogor } \\
\text { (Informan Kunci IV ) }\end{array}$ & 1 & 37 Tahun & Sarjana \\
\hline
\end{tabular}

\section{Pengetahuan}

secara garis besar hampir semua informan inti memiliki pengetahuan yang baik tentang apa yang di maksud dengan perilaku seksual pranikah adalah pegangan tangan, pelukan, bahkan ciuman yang di lakukan sebelum pernikahan seperti yang di ungkapkan sebagai berikut :

"Yang saya tau mah ya pacaran yang berlebihan kaya ciuman, meraba seluruh tubuh, kaya gitu banyak deh" (Informan AI)

"Cewek sama cowok berdekatan pegangan tangan pelukan gitu banyak lagi deh" (Informan B1)

Peneliti kemudian menanyakan kepada guru Bimbingan Penyuluhan (BP) atau Bimbingan Konseling (BK), dan guru kesiswaan sebagai informan kunci tentang pernah atau tidak memberikan pelajaran atau bimbingan yang berkaitan dengan perilaku seksual pranikah remaja, kemudian memberikan penjelasan sebagai berikut :

"Iyah ada kalau dikita pengarahan itu dilakukan dengan kerjamasama bagian kesiswaan yang nanti bentuknya itu seminar, peserta seminarnya adalah siswa siswi yang memang perwakilan darisetiap kelas biasanya sepuluh orang tetapi untuk ke kelas-kelas itu hanya pada saat pelajaran bimbingan konseling aja" (Informan Kunci 1)

\section{Peran Orangtua}

Informasi yang di tanyakan mengenai peran orangtua oleh peneliti terhadap informan adalah informasi yang mencakup pertanyaan tentang seberapa sering bertemu dengan orangtua / wali, seperti apakah kedekatan emosional dengan orangtua / wali dalam segi komunikasi, serta nasihat atau anjuran dan sikap larangan apa saja yang telah di berikan dalam hal yang mengenai tentang perilaku seksual pranikah pada remaja kepada informan.

Dalam hal ini semua informan yang di teliti tinggal bersama dengan orangtua / wali dan ketika di tanyakan mengenai seberapa sering bertemu dengan orangtua / wali hampir semua informan mengutarakan pernyataan sebagai berikut :

"Sama orangtua sering ketemu tapi kan kerja juga ketemunya ga full tapi kerja nya pp sih tiap hari” (Informan A3) 
"Satu rumah kan sering ketemu"

(Informan B3)

Mengenai peran dan komunikasi orangtua dengan informan dalam hal ini, informan kunci menjelaskan bahwasanya siswa-siswi SMK X Kabupaten bogor selalu tentang apa yang dilakukan ketika memiliki masalah dengan orangtua seperti yang di jelaskan sebagai berikut :

"Banyak mas, ada aja mereka merasa gimana gitu yaaa karena awal mula yang saya kejar adalah hubungan mereka dengan keluarga dan mereka menyadari dan mngakui bahwa peran oangtua dirumah itu sangat penting gitu." (Informan Kunci I)

"Nah kalau punya masalah dengan orangtua kebetulan bapak pernah survei ke anak-anak mayoritas disini yang pelanggaran disiplin gitu yah entah itu kesiangan atau yang lain rata-rata di rumahnya ada masalah keluarga bisa masalah dia dengan orangtua atau orangtua dengan orang tua tapi si anak menyaksikan biasanya bercerita sekiranya guru yang bisa nampung buat solusi gitu” (Informan Kunci II) ada yang menceritakan dan meminta solusi

\section{Pemahaman Agama}

Berdasarkan penelitian yang sudah dilakukan oleh peneliti dalam hal kegiatan keagamaan yang diikuti di lingkungan sekolah dan masyarakat, didapatkan bahwa informan mengenai hal ini ada yang mengikuti di lingkungan sekolah dan masyarakat, juga ada sebagian informan yang hanya mengikuti agenda kegiatan kajian rutin yang ada di sekolah seperti yang di utarakan sebagai berikut:

"Kalau pengajian gitu disekolah doang di rumah mah engga ada soalnya" (Informan A2)

"Disekolah ikut, di rumah engga ada atau di lingkungan rumah ga ada pengajian dan lain-lain" (Informan B3)

Wali kelas (Informan Kunci III) ketika di wawancara juga memberikan pernyataan sebagai berikut :

"Kita harus ngasih banyak pemahaman kepada murid apalagi tentang agama di berikan banyak penjelasan tentang hal apa saja yang di akibatkan oleh pacaran dan dampak kesehatan apa saja yang akan terjadi dari perbuatan yang mereka lakukan yang condong ke arah pacaran tersebut" (Informan Kunci III)

\section{Pembahasan}

\section{Karakteristik Informan}

Jumlah informan keseluruhan adalah 15 orang. Informan utama atau informan inti dalam penelitian ini berjumlah 10 orang yang terdiri dari 5 orang yang sedang berpacaran dan 5 orang yang pernah berpacaran. Sebagai informan kunci adalah guru bimbingan penyuluhan (BP) atau bimbingan konseling (BK), guru kesiswaan, wali kelas, dan kepala sekolah.

\section{Pengetahuan}

Dari hasil penelitian dapat di ketahui bahwa pengetahuan informan tentang apa itu perilaku seksual pranikah cukup baik hanya saja informan dalam hal ini memberikan pernyataan secara umum dan kurang memberikan informasi secara mendalam dan hanya sedikit dari informan yang menjelaskan secara mendalam tentang apa saja yang termasuk kedalam perilaku seksual pranikah secara jelas dan yang sesuai dengan harapan dari peneliti mengenai informasi yang di tanyakan.

\section{Peran Orangtua}

Berdasarkan hasil penelitian dengan menggunakan metode wawancara mendalam dan menggunakan pedoman wawancara di dapatkan informasi bahwa rata-rata informan 
meski sering bertemu dengan orangtua masih belum berani mengutarakan apa yang ingin di sampaikan mengenai tentang perilaku seksual, berpacaran dan perkembangan seks (Pubertas).

Ketertutupan orangtua dalam memberikan informasi tentang seksualitas dan kesehatan reproduksi akan mendorong remaja untuk mengetahui seksualitas dan kesehatan reproduksi dengan caranya sendiri. Orangtua dapat mempengaruhi perilaku seksual anaknya melalui tiga cara yaitu komunikasi, bertindak sebagai contoh, dan pengawasan.

\section{Pemahaman Agama}

Dari hasil penelitian wawancara mendalam yang dilakukan terhadap 10 infroman baik itu yang sedang berpacaran maupun pernah berpacaran di dapatkan

\section{Kesimpulan}

Berdasarkan hasil penelitian tentang Faktor-Faktor yang Mempengaruhi Perilaku Seksual Pranikah pada Remaja di SMK X Kabupaten Bogor Tahun 2019 dapat ditarik kesimpulan sebagai berikut :

Pengetahuan siswa-siswi SMK $X$ Kabupaten Bogor tentang perilaku seksual pranikah pada remaja sebenarnya sudah cukup baik, hanya informan dalam hal ini menjelaskan secara umum saja, tidak terlalu menjelaskan secara mendalam tentang apa saja yang termasuk kedalam perbuatan perilaku seksual pranikah.hal ini di karenakan masih memliki anggapan bahwa memberikan informasi seksualitas secara mendalam dapat menimbulkan anggapan bahwa apa yang di jelaskan tersebut dilakukan.

Peran orangtua dalam hal memberikan contoh serta tauladan yang baik bagi anak nya dalam hal pencegahan tentang perilaku informasi bahwa informan pada umumnya hanya mengikuti kegiatan keagamaan yang ada di lingkungan sekolah dan hanya sebagian kecil dari informan yang memiliki agenda kegiatan keagamaan yang ada di lingkungan masyarakat.

Dengan demikian peneliti berpendapat bahwa ada pengaruh antara kegiatan keagamaan yang jarang diikuti oleh informan dengan marak nya kasus perilaku seksual yang banyak terjadi belakangan ini, hal ini di karenakan pada jaman milenial seperti sekarang ini informasi apapun yang di inginkan begitu sangat mudah di dapatkan dengan perkembangan teknologi yang meningkat sangat pesat dan kurangnya pemahaman serta kegiatan keagamaan di perkirakan hal yang condong ke arah negative lebih mudah dilakukan.

seksual pranikah pada remaja di kategorikan cukup baik, hanya dalam hal ini informan dan juga orangtua masih jarang membicarakan tentang perilaku seksual karena masih di anggap tabu dan informan dalam hal ini masih banyak yang belum berani menanyakan kepada orangtua di karenakan alasan takut dan kurang percaya diri bila harus membicarakan perilaku seksual kepada orangtuanya.

Ketaatan beragama yang ada pada informan dalam hal ini banyak informan yang hanya mengikuti kegiatan agenda keagamaan yang hanya ada di sekolah sedangkan di lingkungan masyarakat tidak terdapat kegiatan keagamaan lainya. dari jumlah informan yang di teliti hanya sebagian kecil yang mengatakan bahwa mengikuti kegiatan keagamaan yang di lakukan di lingkungan sekolah maupun masyarakat. 


\section{Daftar Pustaka}

[1] Amelia, Citra. 2018. Determinan Perilaku Seksual Pranikah Remaja SMA di Kecamatan Jatiasih Kota Bekasi Tahun 2018. Depok : FKM UI

[2] Anggraini, Fitri. 2013. Hubungan antara Pengetahuan Seks Pranikahterhadap Sikap Seks Pranikah Remaja di SMKN 1 Bogor. Tahun 2012. Depok: FKM UI.

[3] Anniswah, Nadra. 2016. Faktor-Faktor yang Berhubungan dengan Perilaku Seksual Berisiko IMS pada Remaja Pria di Indonesia (Analisis Data Survei Demografi dan Kesehatan Indonesia Tahun 2012). Univeritas Islam Negeri Syarif Hidayatullah Jakarta.

[4] Arikunto, Suharsimi 2005. Manajemen Penelitian. Jakarta: Rineka Cipta

[5] Azwar, Saifudin. 2013. Sikap Manusia Teori dan Pengukuranya. Yogyakarta: Pustaka Pelajar.

[6] BKKBN. 2007. Himpunan Materi Komunikasi Informasi Edukasi Kesehatan Reproduksi Remaja: jakarta.

[7] Darmasih, Ririn. 2009. Faktor yang Mempengaruhi Perilaku Seks Pranikah pada Remaja SMA di Surakarta. Universitas Muhammadiyah Surakarta

[8] Delyana. 2015. Pengaruh Pendidikan Kesehatan Seksual terhadap Tingkat Pengetahuan dan Sikap Seks Bebas pada Remaja di SMKN 1 Bantul. Yogyakarta: STIKES Aisyiyah.

[9] Desmita. 2013. Psikologi Perkembangan. Bandung. PT Remaja Rosdakarya

[10] Dewi. Kusuma Pujianti. 2012. Gambaran Faktor-faktor risiko Perilaku Seksual Remaja SMA di Wilayah Kerja Puskesmas Halmahera Kota Semarang Tahun 2012. Depok : FKM UI.

[11] Dewi. Novi Saputri. 2015. FaktorFaktor yang Mempengaruhi Perilaku
Seks Pranikah pada Siswa Kelas XI SMK Muhammadiyah Bantul Yogyakarta. Yogyakarta: Sekolah Tinggi Ilmu Kesehatan AISYIYAH.

[12] Hidayati, Nurul. 2016. Hubungan antara Pengetahuan dengan Seks Pranikah dengan Sikap Menolak Terhadap Seks Pranikah Siswa Kelas XI SMAN 1 Pundong. Yogyakarta: Universitas Islam Negeri Sunan Kalijaga.

[13] Hurnlock, Elizabeth B. 1980. Psikologi Perkembangan Suatu Pendekatan Sepanjang Rentang Hidup (Istiwidayanti \& Soedjarwo, penerjemah). Jakarta: Penerbit Erlangga.

[14] Irnawati. 2017. Perilaku Seksual Pranikah (Premartial Sex) pada Remaja Kajian Sosiologis tentang Faktor Penyebab dan Dampak Melakukan Hubungan Seksual Pranikah (Studi di Kecamatan Kalianda Kabupaten Lampung Selatan): Universitas Lampung.

[15] Kementrian Kesehatan RI. 2009 Situasi Kesehatan Reproduksi Remaja. Jakarta: Pusat Data dan Informasi Kementrian Kesehatan RI.

[16] Kementrian Kesehatan RI. 2009. Modul Pelatihan Intervensi Perubahan Perilaku Seks, Seksualitas dan Jender. Jakarta: Kementrian Kesehatan Republik Indonesia.

[17] Na'mah, L. 2014. Seks Pranikah Remaja (Penyebab, Perilaku, dan Dampak) Studi Kasus Kelompok Mahasiswa dan Remaja SMA di Kabupaten Kebumen. Surakarta: Program Pasca Sarjana UNS.

118] Notoadmodjo, Soekidjo. 2010. Metodologi Penelitian Kesehatan. Jakarta: Rineka Cipta. 
[19] Notoadmodjo, Soekidjo. 2007. Promosi Kesehatan dan Ilmu Perilaku. Jakarta: Rineka Cipta

[20] Novitasari, Rilla. 2013. Pengaruh Penyuluhanterhadap Tingkat Pengetahauan tentang Kesehatan Reproduksi pada Siswa SMPN 24 Surakarta. Surakarta: FK UMS

[21] Nur, Dodi Afif A. 2015. Pengaruh Promosi Kesehatan tentang Kesehatan Reproduksi terhadap Pengetahuan dan Sikap Remaja tentang Seks Pranikah di SMA Muhammadiyah 4 Kartasura. Surakarta: Universitas Muhammadiyah Surakarta.

[22] Santrock, John W. 1996. Adolescense Perkembangan Remaja (Adelar Shinto B \& Saragih Sherly, Penerjemah). Jakarta: Penerbit Erlangga.

[23] Sarwono, Sarlito W. 2010. Psikologi Umum. Jakarta: Rajawali Pers.

[24] Sarwono, Wirawan. 2008. Psikologi Remaja. Jakarta: PT Raja Grafindo Persada
[25] Septiana. 2014. Pengaruh Pendidikan Kesehatan Terhadap Tingkat Pengetahuan tentang Kesehatan Reproduksi pada Siswa SMPN 24 Surakarta. Surakarta: FK UMS.

[26] Soetjiningsih dkk. 2007. Buku Ajar Tumbuh Kembang Remaja dan Permasalahanya. Jakarta: Sagung seto.

[27] Syafrudin. 2015. Ilmu Kesehatan Masyarakat. Jakarta: Trans Info Media.

[28] Tim Penulis Poltekes Depkes Jakarta I. 2010. Kesehatan Remaja Problem dan Solusinya. Aryani. Ratna (Editor). Jakarta: Penerbit Salemba Medika.

[29] Tim Penulis. 2013. Laporan Tahunan SDKI 2012 tentang Kesehatan Reproduksi Remaja. Jakarta: Author.

[30] Yufroni. Anif 2016. Pengaruh Penggunaan Media Power Point dalam Penyuluhan Terhadap Pengetahuan dan Sikap Remaja Tentang Bahaya Seks Pranikah di PSPP Galuh Pakuan Tahun. 2016. Bogor : Universitas Ibn Khaldun 